\title{
カージング ローラー間の繊維移動率
}

$\begin{array}{lllll}\text { 名古屋工業大学 } & \text { 原 } & \text { 川 } & \text { 和 } & \text { 久(会員) } \\ \text { 名古屋工業大学 } & \text { 田 } & \text { 中 } & \text { 賢 } & \text { 治 (会員) }\end{array}$

\section{The Fraction of Fiber Transfer between Carding Rollers \\ Kazuhisa Harakawa and Kenji Tanaka}

Nagoya Institute of Technology, Showa-ku, Nagoya

\begin{abstract}
This report discusses the influence of fiber properties and roller dimensions on the fraction of fiber transfer $P$ between carding rollers. With an ideal fiber transfer model assumed, $\Delta \phi\left(=\phi_{A}-\phi_{B}\right)$ is derived as a function of the fiber length and roller dimensions, where $\phi_{A}$ and $\phi_{B}$ are the angles between fiber and the teeth of rollers A and B respectively, at the ideal fiber transfer point (see Fig. 2).

In order to transfer the fiber nipped by both rollers $\mathrm{A}$ and $\mathrm{B}$ to roller $\mathrm{B}$, it is assumed that $\Delta \phi$ should be larger than a certain value $[\Delta \phi\rfloor$. We call $[\Delta \phi]$ as a critical angle.

A value $[\Delta \phi]$ could be defined experimentally by a change of $P$ with a rate of rollers surface velocity. From experimental results (within some experimental limitations), the value $[\Delta \phi]$ is independent of the fiber length, the kind of fibers, and the acting angle of the garnet wire of roller $\mathrm{B}$.

This result seems to be very instrumental in discussing the phenomena of fiber transfer between carding rollers.

(Received June 16, 1970)

摘 要

目 的 カージングローラー間の瀻維移動率 $P$ と瀻維条件ならびに機械条件との関係を検討する.

成 果 (1) 理想的な繊維移動モデルを仮定して, 㵶維がローラーA からローラーBに移動するとき, 繊維がローラーA 扔よびロ 一ラーBの針の作用面となす角度 $\phi A, \phi B$ の差 $\Delta \phi(=\dot{\phi} A-\phi B)$ が瀻維長招よびローラーの諸元の関数として表わされることを示 した.

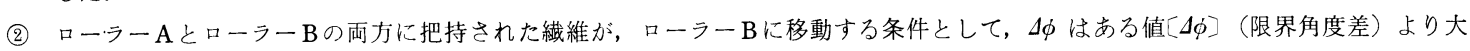

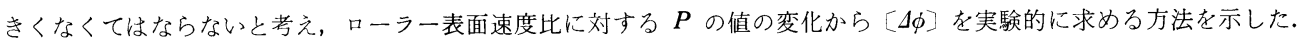

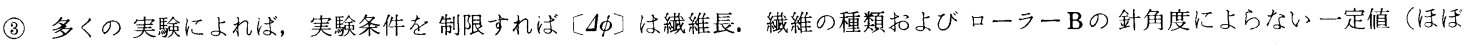
$\left.-20^{\circ} \sim-25^{\circ}\right)$ であることがわかった。
\end{abstract}

（昭和 45 年 6 月 16 日 受理）

\section{1. 緒言}

互いに近接して回転する 2 つのカージング ローラー の1つに繊維を供給すると，供給繊維は他方のローラー にある割合で移動することが一般的に知られている。す なわち，第 1 図に示したように，単位時間当たり $n$ 本の 割合で供給された繊維は，ローラーBによって単位時間 当たり $n_{A}, n_{B}$ 本に分離する. このとき

$$
\frac{n_{B}}{n_{A}+n_{B}}=P\left(\text { ただし } n_{A}+n_{B}=n\right)
$$

は，ローラー A上の繊維集合がローラーBへ移動する割 合を示す.本報ではこれを繊維移動率とよぶ.

カージングローラー間の 繊維移動についての研究は 多いが (3), 繊維移動の内容にたちいった研究はない. 本報では 1 本の繊維に注目した繊維移動モデルを使って 繊維条件, ローラ一の回転条件ならびにローラーの機械 


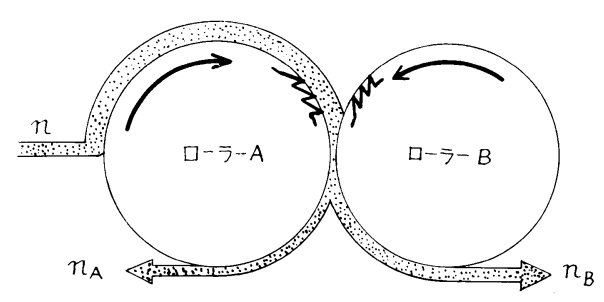

（第 1 困）繊維の移動

的ディメンションを, 繊維集合の問題として定義した繊 維移動率 $P$ に導入することを試みた. この結果を用いる と, 多くの実験結果をある統一された值に整理すること ができるので報告する。

\section{2. 理 論}

\section{1 繊維移動モデルの定義}

第 2 図において，ローラー $\mathrm{A} ， \mathrm{~B}$ の中心線 $\overline{\mathrm{OO}^{\prime}}$ を基 準線とし，ローラー A, Bそれぞれの表面上の点の位置 を $\overline{\mathrm{OO}^{\prime}}$ からの角度 $\delta, \delta^{*}$ (矢印方向を正)で示す. ま たローラー A， B の回転方向は矢印方向を正とする．以 下(1)〜(4)に理想化した繊維移動のモデルを定義する.

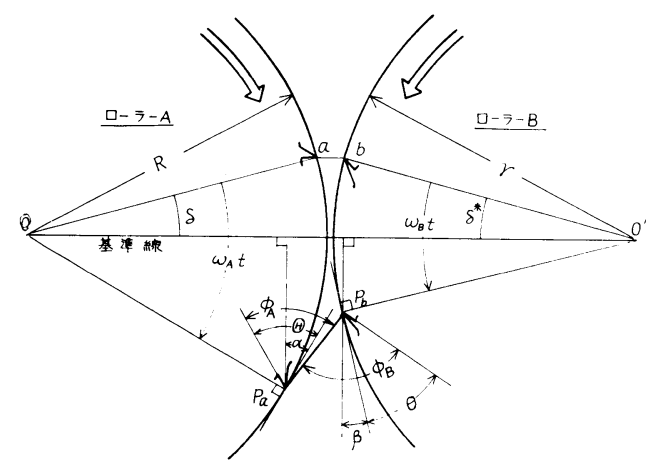

(第 2 図) 繊維移動モデル

（注）両ローラー間のゲージを無視する

(1) ローラー $\mathrm{A}$ の針 $\mathrm{a}$ の把持されて運ばれてきた繊維が 角度 $\delta$ の位置にきたとき，その繊維の一部は針 $\mathrm{a}$ に把持 されたまま，ローラーBの針bにも把持される，てのよ うになる瞬間における針 $\mathrm{a}$ の位置を把持点とよぶ. この 瞬間における $\mathrm{a} ， \mathrm{~b}$ の $\mathrm{OO}^{\prime}$ に対する岳直距離は等しい と仮定する．乙のときの針 $\mathrm{b}$ の位置を $\delta^{*}$ で表わせば， ローラー $\mathrm{A}, \mathrm{B} の$ 半㺯 $R, r$ が極端に異なるものでなけ れば

$$
\delta \cdot R \fallingdotseq \delta^{*} \cdot r
$$

である.

(2) 把持点 $\delta$ は一定值でなく, 分布をむつ之仮定する.

(3) 針 $\mathrm{a}, \mathrm{b}$ の両者に把持された上記の繊維は, 両者に 把持されたまま運ばれる. 針 $\mathbf{a}$ が把持点 $\delta$ から $\angle \omega_{A} t$,
針 b が把持点 $\delta^{*}$ から $\angle \omega_{B} t$ だけ移動し, 針 $\mathbf{a}$ 亡針 $\mathrm{b} の$ 先端間の距離 $\overline{\boldsymbol{p}_{a} \boldsymbol{p}_{b}}$ が繊維長になったところで, その 繊維は針 $\mathrm{a}$ あるいは針 bのいずれかに移る．乙の点を分 離点とよぶ.

(4)分離点において, 針 $\mathrm{a}$ と針 $\mathrm{b}$ との先端を結んだ直線 に対する針 $\mathbf{a}$ と針 $\mathrm{b}$ の作用面のなす角度を $\phi_{A}, \phi_{B}$ とし たとき, $\Delta \phi=\phi_{A}-\phi_{B}$ がある值〔 $\Delta \phi 〕$ を越えれば繊維は

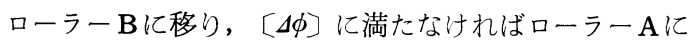

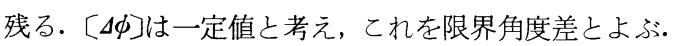

\section{$2.2 K_{V}-\Delta \phi$ 線図}

繊維長を $l$ とし, ローラー A, B および針の働角を第 1 表のように与えると, 任意の $\delta$ に対する $\Delta \phi$ は計算可 能である.

（第 1 表）機 械 条 件

\begin{tabular}{cc|c|c}
\hline & 元 & ローラー & 口-ラーB \\
\hline 針先円半径 $(\mathrm{cm})$ & $R$ & $r$ \\
角速度 $(\mathrm{rad} / \mathrm{sec})$ & $\omega_{A}$ & $\omega_{B}$ \\
針の働角 $(\mathrm{rad})$ & $\Theta$ & $\theta$ \\
\hline
\end{tabular}

$\delta$ と $\delta^{*}$ の間に(1)式が成立し, また把持点から分離点 に至る時間を $\boldsymbol{t}$ とすると，第 2 図において分離点では次 式が成立する.ただし両ローラー間のゲージを無視する.

$$
\begin{aligned}
& l^{2}=\left\{R\left[1-\cos \left(\omega_{A} t+\grave{\dagger}\right)\right]+r\left[1-\cos \left(\omega_{B} t+\hat{o}^{*}\right)\right]\right\}^{2} \\
& +\left\{R \sin \left(\omega_{A} t+\delta\right)-r \sin \left(\omega_{B} t+\delta^{*}\right)\right\}^{2} \quad \cdots \cdots(2)
\end{aligned}
$$
また

$$
\Delta \phi=\phi_{A}-\phi_{B}=\Theta-\theta-\left\{\left(\omega_{A} t+\delta\right)+\left(\omega_{B} t+\delta^{*}\right)\right\} \cdots \cdots(3)
$$
(2)，(3)式加ら $t$ を消去する上，任意の 0 に対する $\Delta \phi$ が 求まる.

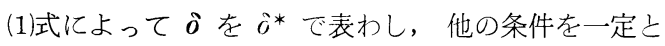
して種々の $\delta^{*}$ に対して, ローラー表面速度比

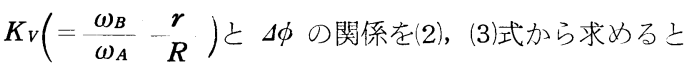
第 3 図になる。

第 4 図は $\delta=\delta^{*}=0^{\circ}$ とし，他の条件を一定として種 々の繊維長 $l$ に対して $K_{V}$ 亡 $\Delta \phi$ の関係を第 3 図之同 様にして求めたあのである。

第 3 図, 第 4 図に示した曲線は, 後述する実験におい て重要な役割をむつ. そこでこ机を特に $K_{V}-\Delta \phi$ 線図 とよぶことにする。

\section{3 繊維移動率 $P$}

前述の $K_{V}-\Delta \phi$ 線図から屯わかるとおり， ローラー A， Bの機械的ディメンションならびに繊維長が与えら れれば, $\Delta \phi$ は把持点 $\delta$ で定まるから

$$
\Delta \phi=\phi(\grave{o})
$$

とする。（第 3 図では $\delta と \delta^{*}$ の間に(1)式が成立する としてっの代わりに $o^{*}$ で考えた）こうすると，分離点 


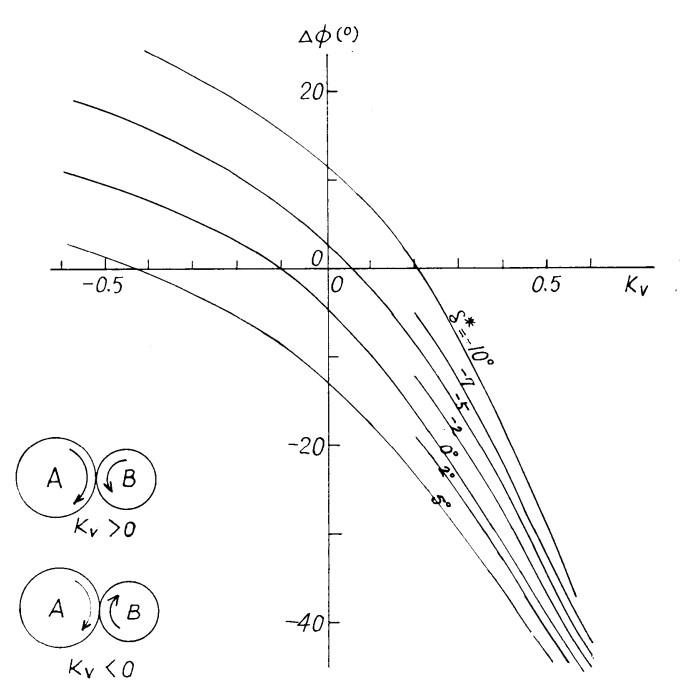

$$
\begin{aligned}
l & =38 \mathrm{~mm}, & \omega_{A}=\frac{\pi}{3} \mathrm{rad} / \mathrm{sec} \\
R & =130 \mathrm{~mm}, & r=78 \mathrm{~mm} \\
\Theta & =80^{\circ}, & \theta=68^{\circ}
\end{aligned}
$$

(第 3 図) $K_{V}-\Delta \phi$ 線図（把持点 $\delta^{*}$ をパラメータ 一とした)

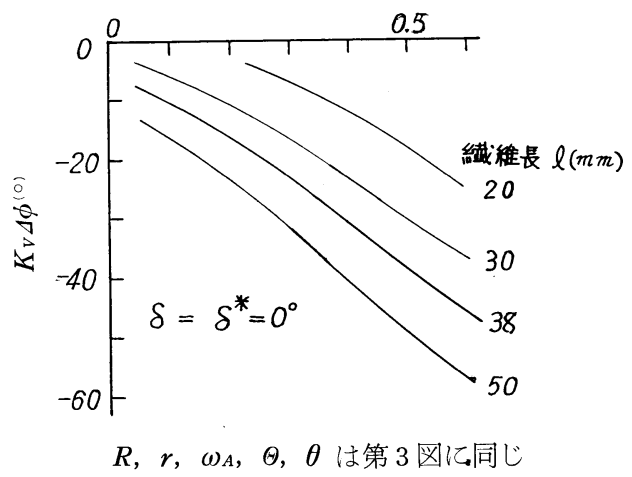

(第 4 図) $K_{V}-\Delta \phi$ 線図（繊維長 $l$ をパラメーター とした）

における繊維の移動条件として定義した 2.14はつぎの ように数式化できる.

$$
P_{M}\{\psi(\delta)\}= \begin{cases}1 & \psi(\hat{o})>[\Delta \phi] \\ 0 & \psi(\hat{o})<[\Delta \phi]\end{cases}
$$

上式で 1 はローラーAからローラーBへの䋊維移動を意 味し，また，0はローラーAへの繊維の残留を意味する あのとする.

さて, 2.1 (2)に述べたように把持点 $\delta$ に間（ $\delta_{\text {min }}$, $\left.\delta_{\max }\right)$ の分布を考え， $\delta$ の位置においてローラーBに新 しく把持される繊維の確率密度分布を $n(\delta)$ とする（た
だし $\left.\int_{\delta \min }^{\delta \max } n(\delta) d \delta=1\right)$ また， $N$ をローラー $\mathrm{A}$ の繊維密度 (繊維数/ローラー $\mathrm{A}$ の中心角), $N^{*}$ を $n(\delta)$ の分布を あつローラーBへの照積繊維密度（繊維数/ローラーA の中心角）とすると

$$
\frac{N^{*}}{N} \int_{\delta \min }^{\delta \max } n(\delta) d \delta
$$

は，ローラーAで運ばれる繊維がローラーBに把持され る割合.

$$
\frac{N^{*}}{N} \int_{\delta \min }^{\delta \max } n(\delta) P_{M}\{\psi(\delta)\} d \delta
$$

は，ローラーAで運ばれる繊維がローラーBに把持され かつ分離点でローラーBに移動する割合，すなわち繊維 移動率 $P$ である。

2.4 繊維移動率 $P$ 上ローラ一表面速度比 $K_{V}$ の関係 先に述べた繊維移動モデルを適用した場合, 繊維移動 率 $P$ とローラーの機械的ディメンション（ローラー径, 針の働角など）および繊維長との関係を検討することが 可能となる。乙こではローラ一表面速度比 $K_{V}$ と繊維 移動率 $P$ の関係を図式的に説明する.

ローラー A, Bの径, 針の働角, ローラー $\mathrm{A}$ の回転速 度が一定であれば， $N^{*}, n(\delta)$ はローラーBの回転速度 によって変わらないと仮定する また説明の都合上, 把 持点 $\delta$ は第 5 図に示したように, 区間 $\left(-10^{\circ}, 0^{\circ}\right)$ に分 布し, 分布 $n(\delta)$ は $\delta=-5^{\circ}$ に対して左右対称と仮定 する・
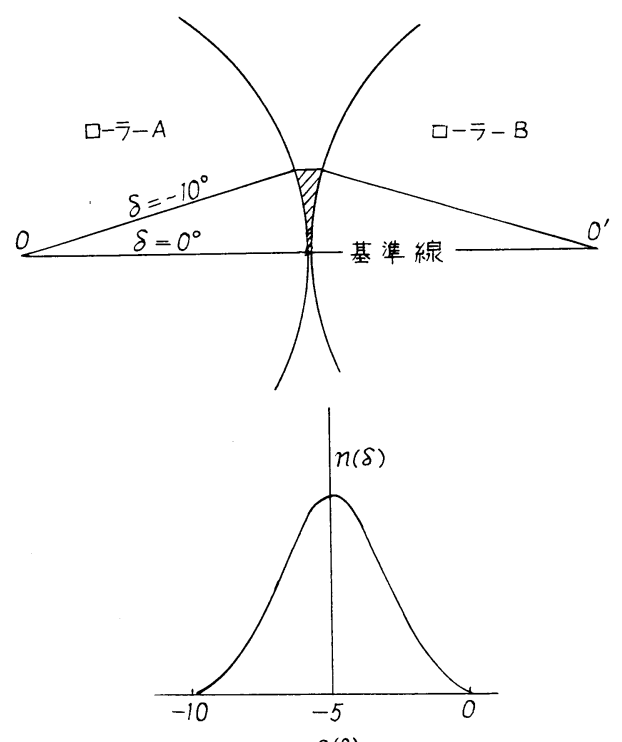

$\delta^{(0)}$

（第 5 図）把持点分布（仮定） 


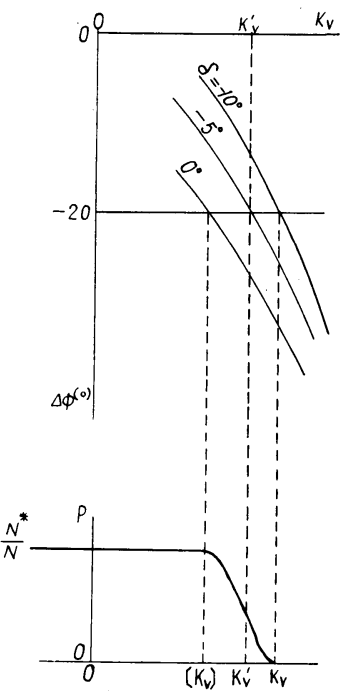

（第.6図）繊維移動モデルにおける 移動率 $P$ と $K_{V}$ の関係

第 6 図上段は, 把持点 $\delta$ をパラメーターとした $K_{V}-$ $\Delta \phi$ 線図とする。図からローラー表面速度比が $K_{V^{\prime}}$ の とき, 把持点が $-5^{\circ}$ の繊維が分離点に至ったときの $\Delta \phi$ はー20である。

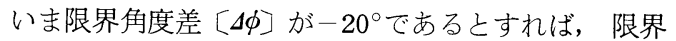
角度差の定義から，ローラー表面速度比が $K_{V^{\prime}}$ におい ては, $\delta>-5^{\circ}$ を把持点とするすべての繊維について

$$
P_{M}\{\phi(\delta)\}=0
$$

また $\delta<-5^{\circ}$ を把持点とするすべての繊維について

$$
P_{M}\{\psi(\delta)\}=1
$$

したがって，繊維移動率 $P$ は(7)式から

$$
\begin{aligned}
P & =\frac{N^{*}}{N} \int_{-10^{\circ}}^{0^{\circ}} n(\delta) P_{M}\{\psi(\delta)\} p \delta \\
& =\frac{N^{*}}{N}\left[\int_{-10^{\circ}}^{-5^{\circ}} n(\delta) P_{M}\{\psi(\delta)\} d \delta+\int_{-5^{\circ}}^{0^{\circ}} n(\delta) P_{M}\{\psi(\delta)\} d \delta\right] \\
& =\frac{N^{*}}{N} \int_{-10^{\circ}}^{-5^{\circ}} n(\delta) d \delta
\end{aligned}
$$

$n(\delta)$ の $\delta=-5^{\circ}$ に対する対称の仮定から

$$
=-\frac{1}{2} \frac{N^{*}}{N}
$$

となる，てのようにして任意の $K_{V}$ に対する $P$ を求める ことができる.

$K_{V}$ に対する $P$ の変化を図示したのが第 6 図下段であ る. すなおち繊維移動率 $P$ は $K_{V}<\left[K_{V}\right]$ の範囲では一 定値 $\frac{N^{*}}{N}$ を示すが， $K_{V}>\left[K_{V}\right]$ の範囲では $K_{V}$ の増加 とともに減少し，ついには 0 となる。

\section{3. 実験的検討}

\section{1 繊維移動率 $P$ の測定法}

以後に述べる実験で用いた繊維移動率 $P$ の測定は，つ ぎの 2 種類の方法による.

（i）ローラーAの繊維密度の減少率による方法.

ローラーAの繊維量が適当であれば，その反射光量は ローラーAの繊維密度に比例する4). 第 7 図はローラー $\mathrm{A}$ 織維密度の光学的測定の記録例である.

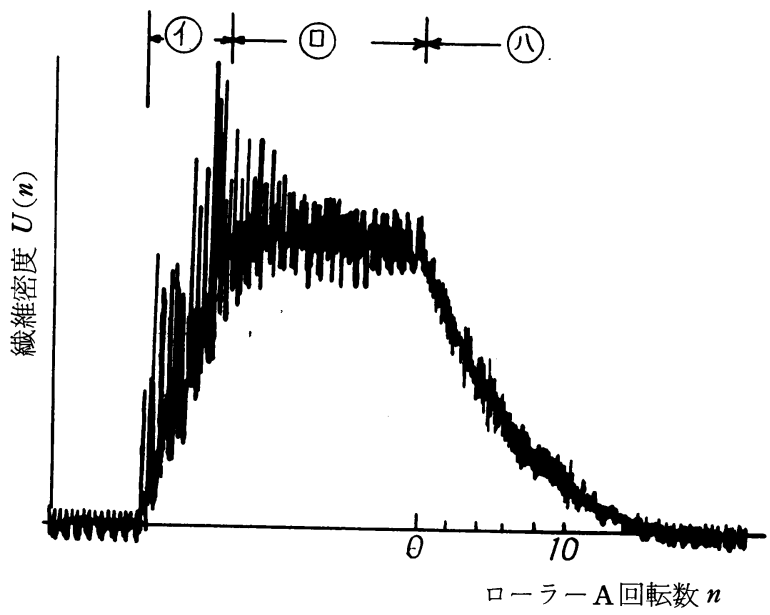

（第 7 図）ローラーA 繊維密度の光学的記録

初めローラーBを停止し, ローラーAに細分した繊維 を供給すると（図中(1)），供給繊維はローラーAに設け たフラットの作用で，ローラー上に均一に拡散する（図 中回). その時点でローラーBを始動するとローラー A の繊維密度は減衰を始める (図中). 繊維密度の光学 的測定器についての説明は別報》にゆずる.

ローラーBの始動時からのローラー $\mathrm{A}$ の回転数 $n$ に対 するローラー $\mathrm{A}$ 上繊維密度を $U(n)$ とすると, 䋊維移 動率 $P$ は次式で計算できる.

$$
\begin{aligned}
& P=\frac{\Delta U(n)}{U(n-1)} \\
& \text { ただし } \Delta U(n)=U(n-1)-U(n)
\end{aligned}
$$

この方法で求めた $P$ の值は， $U(n)$ が極端に小さくなら ない範囲でほぼ一定値を示す。

（ii）ローラーAとローラーBに分離した単位時間当た り繊維量の計量による方法

第 1 図において，ローラーAの下部ならびにローラー $\mathrm{B}$ の前部に吸引管を設け，ローラー $\mathrm{A}$ およびローラー $\mathrm{B}$ に分離した繊維を吸引する，単位時間当たり繊維の吸引 量を $W_{A}, W_{B}$ とすると, 繊維移動率は

$P=\frac{W_{B}}{W_{A}+W_{B}}$ （ただし同種類等長繊維の場合） である。 
3.2 ローラー表面速度比 $K_{V}$ による瀻維移動辛 $P$ の 変化

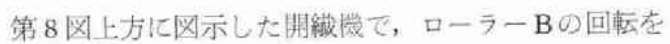

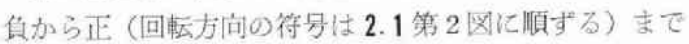
大幅に変化したとき, 瀻維移動率 $P$ の実駼值は第 8 図下 方のようになる。

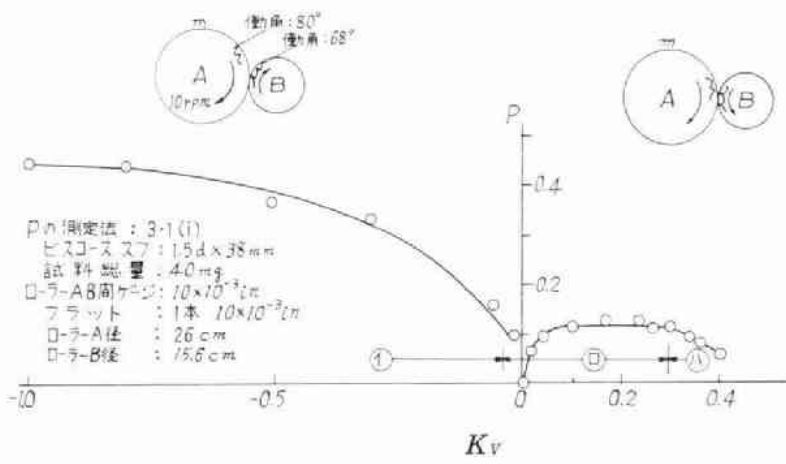

(第8図) ローラー表面速度比 $K_{V}$ 之瀻維移動辛 $P$

$P$ は $K_{V}$ によって大きく变わるが，大ざっばに見て (1)(1003つの頜域に分類てきる。先に瀻維移動モデル を道用して， $K_{V}$ 亿対する $P$ ○变化在理論的に求め, 第 6図下段に示した，そこて，ここては第8四の夷験結果

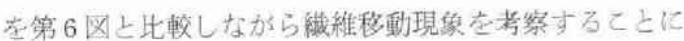
す万. 以下第 8 図を实験 $K_{v}-P$ 線図，第 6 図下段在理 論 $K_{V}-P$ 線四上よかとを江する。

9)制域について

理論 $K_{V}-P$ 線図において, 本領域に相当する $P$ の值 は四領域に相当するそれと同しておる。夷駼 $K_{v}-P$ 線 四での值か大きくなった理由はつぎのように解积てき 3.

一般に分倠点通過後のローラー $\mathrm{A} の$ 蟣維状態は，ロー ラーBへの移動維維の影響で毛羽犬゙つ。一方，本斜城の $K_{V}$ の範囲ては把持点と分離点加互いに近接する。した がって，本領域ではローラーBへ移動する䋐維によるロ ーラーA織維の毛羽だちは把持䋘維を增加するの上同し 効果がある。つまり把持点上分離点加近接するのの範囲

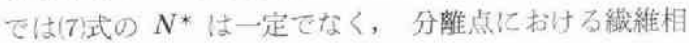
互作用によって增加するもの上考える。

$P$ の实検值の增加は $\left|K_{V}\right|$ が大きいほど著しく，また その增加の程度は綶維の種類によって異なるがとれは 上記の説明之矛盾しない。

(ii)領域上㑯域

$K_{V}$ 加 0 付近の場合をのぎけば, (10，領城の夹験 $K_{V}-P$ 線図は理論 $K_{V}-P$ 線図上同し傾向定示してい


0.3 まで $P$ の実驗值は大略一定值在示すか， $K_{V}$ 加 0.3 以
上では $K_{V}$ の增加上とあにPの值は減少する。これは

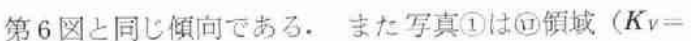
0.25ににおける緎維の分離状態を接写したすのであるか

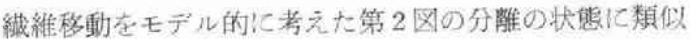
している、したがって本頒域さは, 前述の繊維移動モデ ルを適用して，移動現象を考察することが可能さある j.

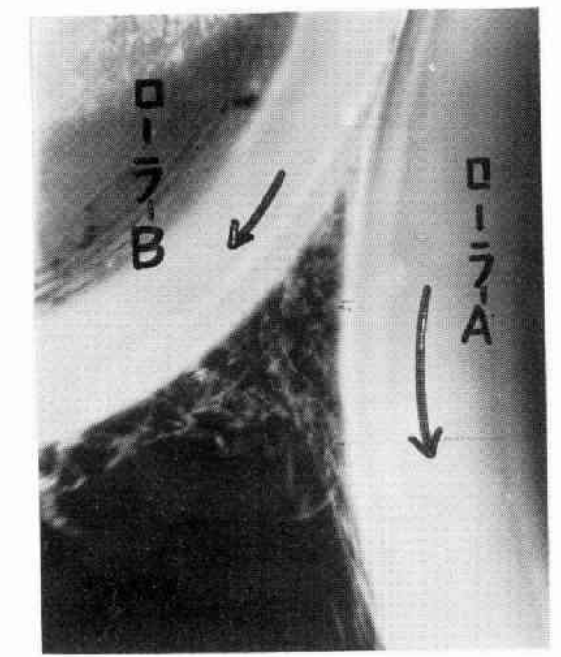

試料：ビスコーススフ $1.5 \mathrm{~d} \times 38 \mathrm{~mm}$ $K_{V}: 0.25$

KV 加滴当で瀻維はローラーB!とよく移動している 军 真 1

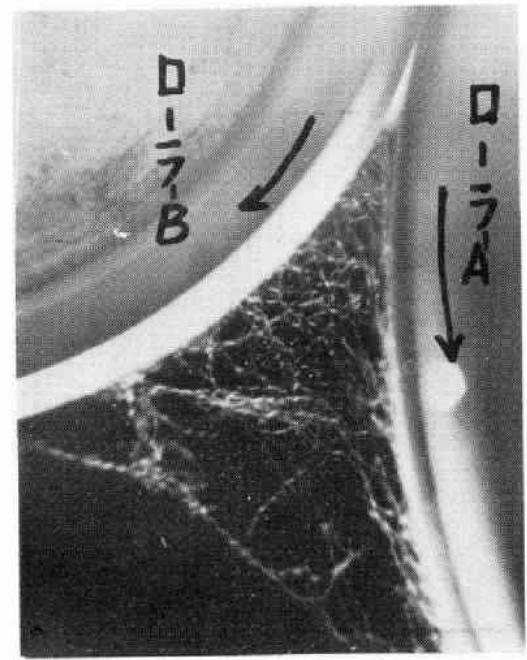

陚料：ポリエステルスフ $1.25 \mathrm{~d} \times 38 \mathrm{~mm}$ $K_{V}: 0.05$

$K_{V}$ が小さくローラーBに一度移動した緎維が再ひ ローラーAに引きもどされている. 陚料がピスコー ススフ $1.5 \mathrm{~d} \times 38 \mathrm{~mm}$ の場合には $K_{V}$ か 0.15 前後ま でこの現像が明らかに見られる。

写 真 (2) 


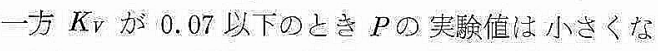

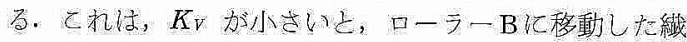
維が再びローラーAの䋐維と加らうかって，ローラーA

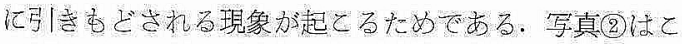
の状態写写したものでる.

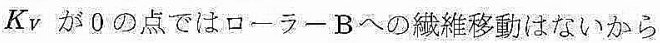

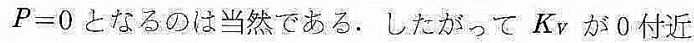

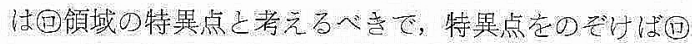
○領域では(7)式がてのまむ適用できるすのと考える.

3.3 限界角度差 [ $\Delta \phi$ ]について

3.3.1 $[\Delta \phi] \circlearrowleft$ 害験的測定法

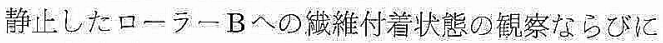
後述可る把持点分布 $n(\delta)$ 笑験結果加 ーラーが互いて正力向 (第 2 図参照) に回転する場合

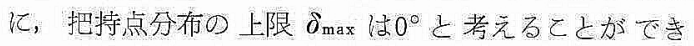
3 .

したかっって，日一ラ一表面速度比 $K_{V}$ を增加したと

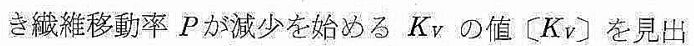
L， $K_{V}-\Delta \phi$ 線网 $\delta=0^{\circ}$ の且線老用けて $\left.K_{V}\right]$ 亿対忘

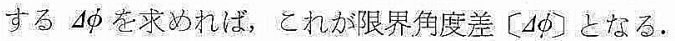
(第 6 図参㩆)

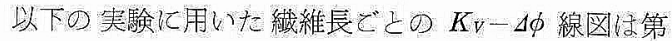

4 図求めてある.

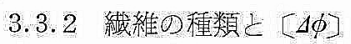

試料放

$\begin{array}{ll}\text { ビスコース フ } & 1.5 \mathrm{~d} \times 38 \mathrm{~mm} \\ \text { ビスコース ス } & 2 \mathrm{~d} \times 22 \mathrm{~mm}, 30 \mathrm{~mm}, 35 \mathrm{~mm}, \\ & 39 \mathrm{~mm}\end{array}$

术りエスデル スフ $1.25 \mathrm{~d} \times 19 \mathrm{~mm}, 38 \mathrm{~mm}$

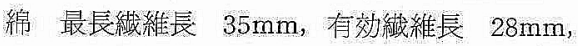
平均瀻維長 $25.4 \mathrm{~mm}$

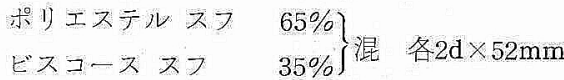
以上 9 種類.

Pの測定は 3.1(i) による. 実験機の機械的ディメン ションを第 2 表に示す. 第 3 表は丰駼結果.

(第 2 表) 奉験機諸元
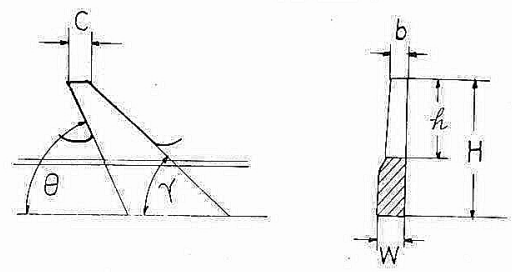

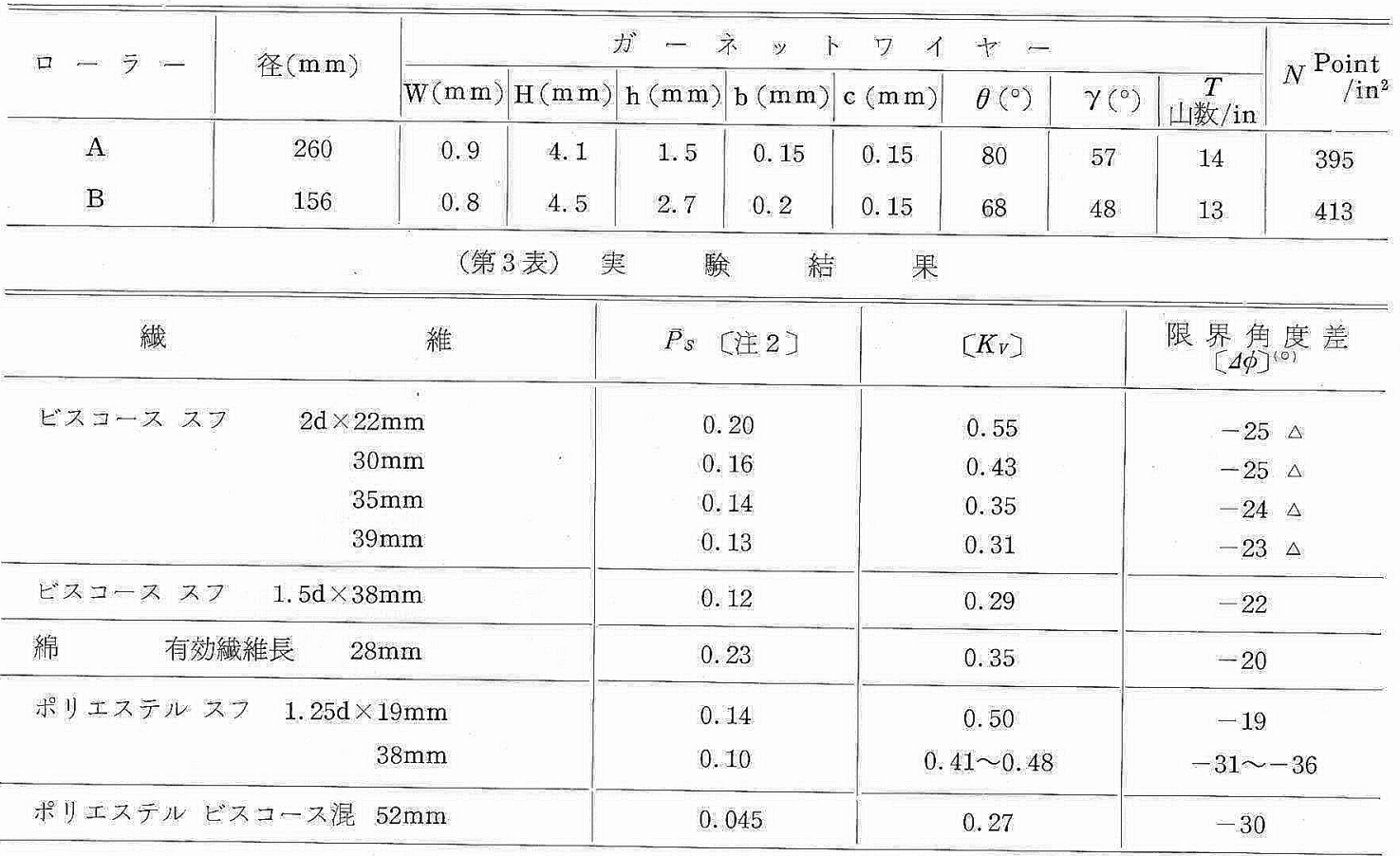

実験条件 ローラーA・フラッ (1A) 間ゲーシ $10 \times 10^{-8}$ in

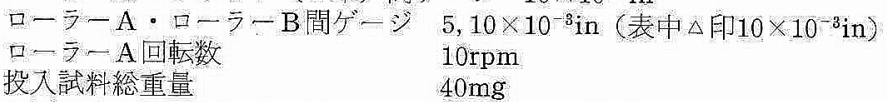

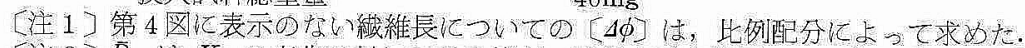

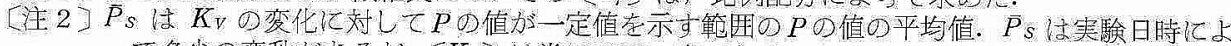

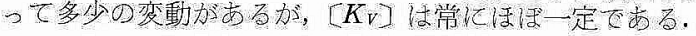


（第 4 表）ガーネットワイヤ一仕様

\begin{tabular}{c|c|c|c|c|c|c|c|c|c}
\hline \hline 口- ラ- & $\theta\left(^{\circ}\right)$ & $\gamma\left({ }^{\circ}\right)$ & $W(\mathrm{~mm})$ & $H(\mathrm{~mm})$ & $h(\mathrm{~mm})$ & $b(\mathrm{~mm})$ & $c(\mathrm{~mm})$ & $\mathrm{T}$ 山数/in & $\begin{array}{c}\mathrm{Npoint} \\
/ \mathrm{in}^{2}\end{array}$ \\
\hline \multirow{2}{*}{$\mathrm{B}$} & 68 & 48 & 0.8 & 4.5 & 2.7 & 0.2 & 0.15 & 13 & 413 \\
& 60 & 44 & 0.9 & 5.3 & 3.3 & 0.2 & 0.15 & 12 & 333 \\
\hline A & 80 & 57 & 0.9 & 4.1 & 1.5 & 0.15 & 0.15 & 14 & 395 \\
\hline
\end{tabular}

（注）各記号は第 2 表参照のこと

ビスコース スフにおいては，繊維長 $22 \sim 39 \mathrm{~mm}$ の範

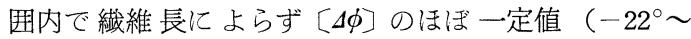
-25) である.

ポリエステル スフ $38 \mathrm{~mm}$ およびポリエステル レー ヨン混では, ビスコース スフに比較して $\left.\bar{P}_{s}, 〔 \Delta \phi\right] と$ あに小さい，一方ポリエステル スフにおいては，繊維

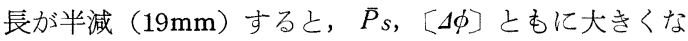
りビスコース スフのそれに類似する。これは明らかに 繊維特性の変化によるためと推定される. すなわち繊維 長が短くなったために，繊維長に対するクリンプの大き さが相対的に大きくなり，ビスコース スフのような挙 動を示すようになったためと推察される.

第 3 表から〔 $\Delta \phi]$ の值は繊維長が極端に異ならない範 囲では，繊維長によらず繊維の種類によって定まる值で あるといえる。

\section{3 .3 針の働角之 $[\Delta \phi]$}

(3)式から明らかなように，ローラーBの針の働角 $\theta$ を $\Delta \theta$ だけ変更した場合，第 4 図の $K_{V}-\Delta \phi$ 線図は垂直方 向に- $\Delta \theta$ だけ平行移動する.ここでは $\theta$ が $68^{\circ}$ (3.3.2

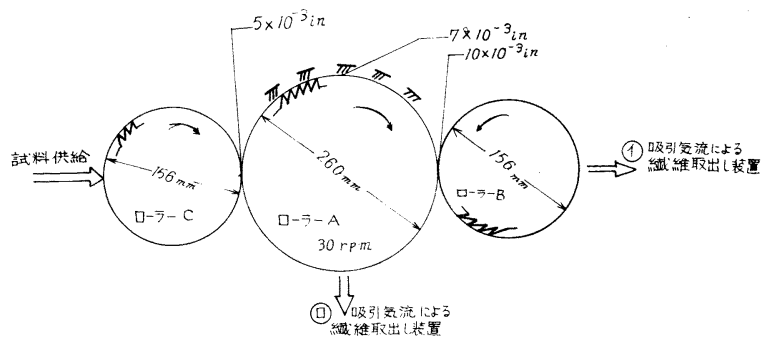

（第 9 図）実 験 装 置

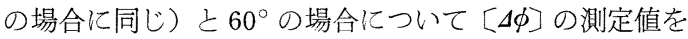
比較する.

$$
\begin{aligned}
\text { 試料は } & \text { ビスコース スフ } & 1.5 \mathrm{~d} \times 38 \mathrm{~mm}, \\
& \text { ポリエステル スフ } & 1.25 \mathrm{~d} \times 38 \mathrm{~mm},
\end{aligned}
$$

の 2 種類を，それぞれ連条 1 回通しスライバーにして， 第 9 困に示した実験機に供給する.

実験機は第 9 図に示したように，試料細分化用ローラ 一 C，ローラーA，ローラーB，ローラーA，Bに分離 した繊維の取出し装置、, (加ら成る・ガーネットワイ ヤ一仕様を第 4 表に示す. $\theta$ が $68^{\circ}$ のあ，ならびに口 ーラーAに使用したガーネットワイヤーは, 3.3.2 第 2

\begin{tabular}{|c|c|c|c|c|}
\hline 織 & $\theta$ & {$\left[K_{V}\right]$} & $\begin{array}{c}\text { 限界角度差 } \\
{[\Delta \phi]\left(^{\circ}\right)}\end{array}$ & $\begin{array}{c}\text { 備 } \\
\text { (考 } \\
\text { 第 } 3 \text { 表の例) } \\
\end{array}$ \\
\hline ビスコース スフ & 68 & 0.26 & -20 & -22 \\
\hline $1.5 \mathrm{~d} \times 38 \mathrm{~mm}$ & 60 & 0.40 & -22.5 & - \\
\hline ポリエステル スフ & 68 & 0.27 & -20 & $-31 \sim-36$ \\
\hline $1.25 \mathrm{~d} \times 38 \mathrm{~mm}$ & 60 & 0.38 & -21 & - \\
\hline
\end{tabular}

(第 5 表) 実 験 結 果

表に示したものと同じものである.

試料の 供給は毎分ほぼ $25 \mathrm{mg}$ で，ローラーA 上では $20 \mathrm{~mm} \sim 30 \mathrm{~mm}$ 幅に広がる. ローラー $\mathrm{A}$ 上緘維密度は非 常に小さい.

第10図万は繊維移動率 $P$ の測定例.

第 5 表は実験結果である.

表から明らかなように， $\theta$ の值に $8^{\circ}$ 差があり $P$ が減

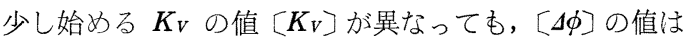
ほぼー $20^{\circ}$ 乙等しく,またてれは緘維の種類によって変

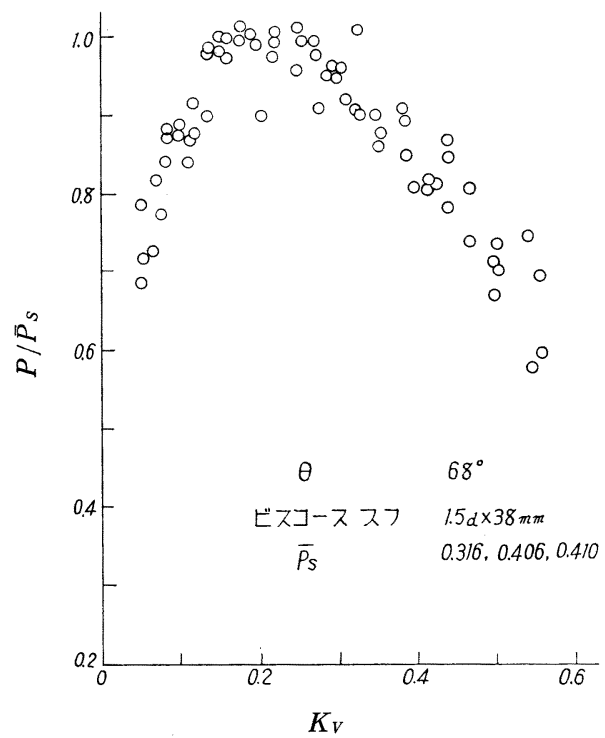

（第10図(1)）実 験 例

〔注〕 $P / \bar{P}_{s}: K_{V}$ の変化に対し $P$ の值が一定值を示す と考えら机る範囲の $P$ の值の平均值を $\bar{P}_{S}$ とす る. 実験日時によって $\bar{P}_{S}$ の值は異なるが，たて 軸を $P / \bar{P}_{S}$ によることによってこれを同じ罒に 示したあのである. 




（第10図(1)）尖 験 例

わらない.

ここでこの結果を 3.3 .2 第 3 表のうち機械条件および 繊維条件が等しい実験結果と比較する(第 5 表備考榴).

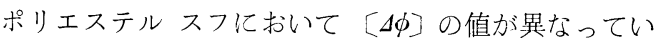
ることがわかる．これは移動率 $P$ の測定法の違いによっ て生じたものと考える.すなわち 3.3 .2 におけるPの测 定は, 比較的にローラーAの䋊維密度が大きい範囲で行 なっているが, 本項に拈ける垁験では繊維密度は非常に 少ない.したがって分離点における繊維相互の7涉に大 きな相違があるものと考えるべきである，てのような緎 維相互干涉についての詳細な検討は别報にゆずる.

\section{3 .4 ま亡め}

繊維移動率 $P$ についてぎのことがわかった。

(1) $P$ はローラー表面速度比 $K_{V}$ に大きく依存する. $P$ と $K_{V}$ の関係は, 第 8 図に示したような一定のパタ ーンをもち， $K_{V}$ の值によって $P$ の定まりかたは一様で ない.

(2) $K_{V}$ を正で增加し， 方る值：[KV] 以上にする上 $P$ は $K_{V}$ の増加とともに減少する.〔KV〕の值は, 纎維 長, 繊維の種類, ローラーBの針角度などで異なる。し かし 2.1 に述べた繊維移動モデルを考慮して， $K_{V}$ 在限

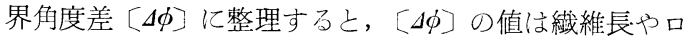
ーラーBの針角度とは無関係な一定谊を示す。しかも口 ーラーAの繊維密度が小さい場合には，繊維の種類にも 無関係となる・本実験では約 $-20^{\circ}$ で市る。

3.4 把持繊維の確率密度分布 $n\left(\hat{o}^{*}\right)$ について

先に定義した $n(\delta)$ の形を奏験的に検傠しょうとし た.ここでは実験の都合上， $\delta$ と $\delta^{*} は(1)$ 式で $1: 1 の$ 刘応をするものとし, 把持点を $\delta^{*}$ で考える.
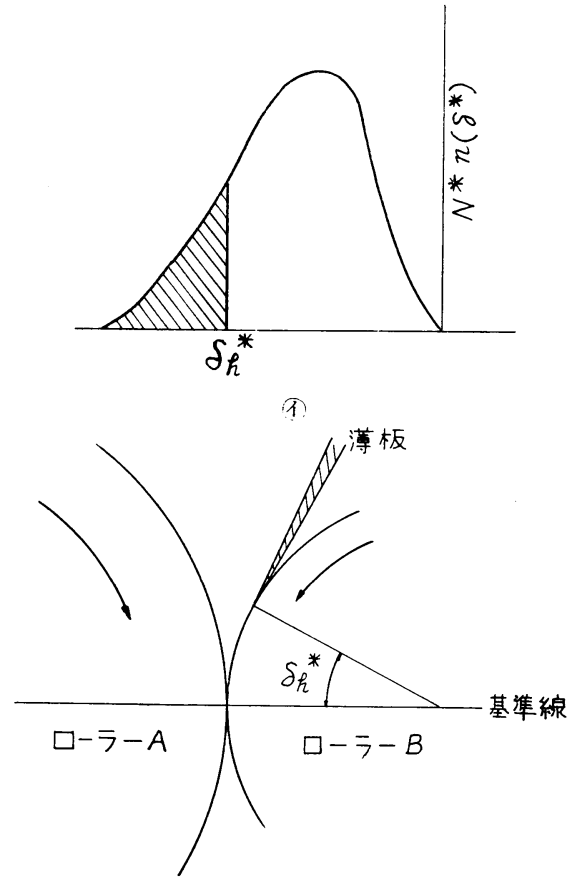

(11)

（第11図）美験方法（下限制限）

3.4 .1 夹験方法および尖験条件

(i) 下限制限による力法

ローラーAからローラーBに繊維が移動する場合に, 把 持点密度が第11図不の尖線のように分布するもの上す る.いま図に示したように，両ローラー間に薄い板を ローラーBにできるだけ近接して基準線より上流側に挿 入し，板の先端位置を基準線に対して $\delta_{h}{ }^{*}$ 上する上, $\delta^{*} \leqq \delta_{h}{ }^{*}$ の点では繊維の把持は不可能となる. そこで図 ○に示したように把持点密度! 蜍線部が切り取られたす のとなると考える．実際に心，插入した板がローラーA の瀻維に影響を及ぼし，分布の形が変化することが予想 されるが，板の插入がそれほど深くない範囲では，この ような影響は無視できるもの上考える。

把持点密度の変化をこのように考え，把持点の上限 $\delta_{\max } *$ が

$$
\psi\left\{\begin{array}{cc}
r & \hat{O}_{\max }^{*} \\
R &
\end{array}\right\}>[\Delta \phi]
$$


繊維移動率 $P_{\delta h^{*}}$ は

$$
\begin{aligned}
& P_{S h} *=\frac{N^{*}}{N} \int_{\delta h^{*}}^{i \max *} n\left(\delta^{*}\right) d \delta^{*} \\
& =\frac{N^{*}}{N}\left[1-\int_{\delta \min }^{\delta^{*}} \underset{h^{*}}{n\left(\delta^{*}\right) d \delta^{*}}\right] \\
& \text { 一方 } P_{\delta \min }{ }^{*}=\frac{N^{*}}{N} \int_{\delta \min ^{*}}^{\varepsilon_{\max }^{*}} \underset{\left.\delta^{*}\right)}{*^{*}} d \delta^{*}=\frac{N^{*}}{N}
\end{aligned}
$$


したがって

$$
\int_{\delta \min }^{\delta h^{*}} n\left(\delta^{*}\right) d \delta^{*}=1-\frac{P_{\delta h^{*}}}{P_{\delta \min }{ }^{*}}
$$

すなわち，薄板の位置 $\delta_{h}{ }^{*}$ 之繊維移動率 $P_{\delta h}{ }^{*}$ の関係 を実験的に求めれば $n\left(\delta^{*}\right)$ を知ることができる.

(ii) 上限制限による方法

把持区間の上限を（i）と同じ方法で制限することは不 可能であるが，ローラー表面速度比 $K_{V}$ を変化すること によって上限を制限するのと同じ効果を期待できる。

これを図式的に説明する. 第 6 四下段でローラー表面 速度比 $K_{V}$ が $K_{V^{\prime}}$ のとき, 纎維移動率 $P$ が $N^{*} / N$ と 比べて減少した理由は(5)式の条件から，区間 $0^{\circ} \sim-5^{\circ}$ を 把持点とする繊維がローラー A 亿残存するためである. すなわち，ローラー表面速度比を $K_{V}{ }^{\prime}$ に設定するとと は，把持点の上限を一 $5^{\circ}\left(\delta^{*}\right.$ につては $\left.-5^{\frac{r}{R}}{ }^{(0)}\right)$ に制限したことと同じ効果があるといえよう.

$K_{V}$ 之上限制限 $\delta_{l}^{*}$ の関係は $K_{V}-\Delta \phi$ 線四加ら導く ことができる.すなおち第 12 図のは纎維長 $38 \mathrm{~mm}$ のと き，把持点 $\delta^{*}$ をパラメーターとして描いた $K_{V}-\Delta \phi$ 線 図である。いま限界角度差を一 $-22^{\circ}$ とすると, 上限制限 $\delta l^{*}$ は各線罒方 $-22^{\circ}$ となる $K_{V}$ の值と各線四のパラメ

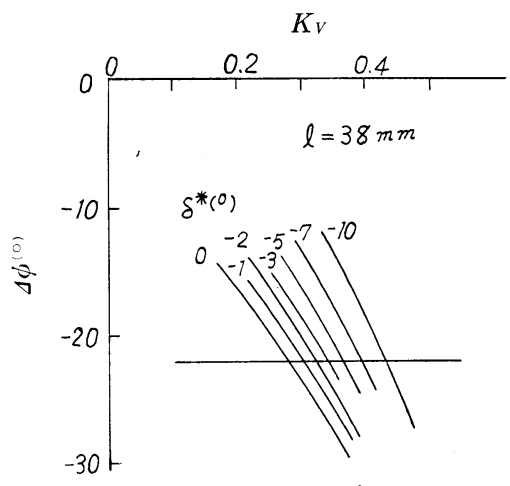

(1) $K_{V}-\Delta \phi$



(ii) $K_{V}-\grave{o}^{*}$ *

（第12図）実験方法（上限制限）

〔注〕実験機諸元は第 2 表に順ずる． $\boldsymbol{\delta}_{\max }{ }^{*}=0^{\circ}$ を仮定

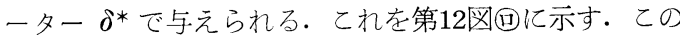
ようにして上限制限 $\delta \iota^{*}$ と $K_{V}$ の対応が定まったとき 繊維移動率 $P_{\delta l} *$ は

$$
P_{\delta l^{*}}=\frac{N^{*}}{N} \int_{\delta \min { }^{*}}^{\delta l^{*}} n\left(\delta^{*}\right) d \delta^{*}
$$

したがって

$$
\frac{P_{\delta l^{*}}{ }^{*}}{P_{\delta \max }^{*}}=\int_{\delta \min }^{\delta l^{*}} n\left(\delta^{*}\right) d \delta^{*}
$$

すなわち，ローラ一表面速度比 $K_{V}$ 亡繊維移動率 $P_{\delta} \iota^{*}$ の関係を実験的に求めれば $n\left(\delta^{*}\right)$ を知ることができ 万.

(iii） 実験条件

試料はビスコース スフ $1.5 \mathrm{~d} \times 38 \mathrm{~mm}$. 繊維移動率 $P$ の 測定は3.1(i) による.ただし投入試料総量は $40 \mathrm{mg}$. 実験機は第 2 表に示したものと同じ．機械条件は

$$
\begin{aligned}
& \text { ローラーA〜ローラーB間ゲージ } \quad 7 \times 10^{-3} \text { in } \\
& \text { ローラーA〜フラット間ゲージ } \\
& \text { (フラットは } 1 \text { 本設置) } 9 \times 10^{-3} \mathrm{in} \\
& \text { ローラーAの回転速度 } \\
& 10 \mathrm{rpm}
\end{aligned}
$$

なお下限制限用板は $0.3 \mathrm{~mm}$ 厚アルミニュウム板で, 先 端をナイフエッジに加工したあのを用いた。

\section{4 .2 実験結果および考察}

第13図の@は下限制限ならびに上限制限による瀻維移 動率 $P$ の測定結果.はの@の各測定值をむすんだ曲線 (実線) から，(8)，(9)式を用いて求めた $n\left(\delta^{*}\right)$ である.

四@に示した 3 つ分布曲線のうち $\mathrm{a}$ は $\mathrm{b} ， \mathrm{c}$ とは大 きく相違している.こ机はローラーAの繊維状態に対す る薄板捜入の影響が無視できないためと考える．すなわ ち図すで $-5^{\circ}$ 付近から $\delta_{h}{ }^{*}$ が増加するにつれて（湢板の 挿入が梁くなるにつ机て),$P$ の值は急激に減少する.

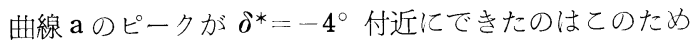
である・したがって，信頼できる曲線 $\mathrm{a} の$ 範囲は，たか だか $\delta^{*}$ がー $8^{\circ} \sim-6^{\circ}$ 付近に限られる.

以上のように実験に不都合な点があるが，曲線aから 把持点は $-8^{\circ} \sim 0^{\circ}$ の間に分布するということができよ う.とれは, 最小ゲージ点を通過後, 改めてローラーB に把持される繊維はないことを意味するのであるが，静 止したローラーBへの繊維付着状態の観察からあ $\boldsymbol{o}_{\text {max }}{ }^{*}$ はほぼ $0^{\circ}$ と考えられるし，また直観的にも妥当な結論と いえよう。

把持点分布区間についての上述の結論から，曲線 $\mathbf{b}$, c において $\delta_{\max }{ }^{*}=0^{\circ}$ 在仮定したことは妥当である.し かし曲線 b， c についてあ不都合な点がある.すなわち 曲線 $\mathrm{b}$ において，把持点は $-10^{\circ}$ 付近まで分布すること になりとれは前述の結論と一致しない。また曲線 $\mathrm{c} に$ おいては，薄板で下限を一 $3.5^{\circ}$ に制限したにあかかわら ず，把持点はそ机以上に分布することを示している。乙 


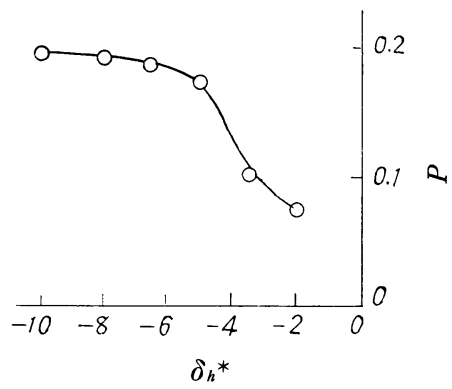

(1) 下限制限によるPの測定結果

〔注〕ローラー表面速度比 $K_{V}: 0.21$

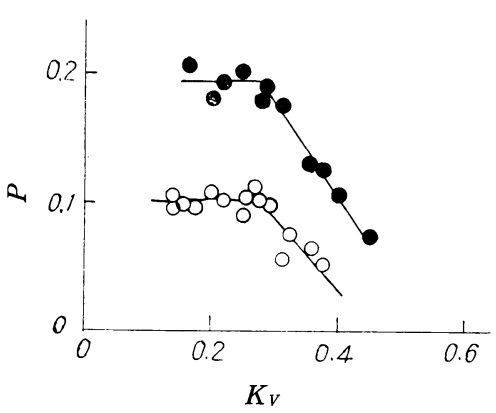

(10)上限制限によるPの測定結果

〔注〕 $○ \cdots$ 下限を $-3.5^{\circ}$ 亿制限

・…下限は自然状態

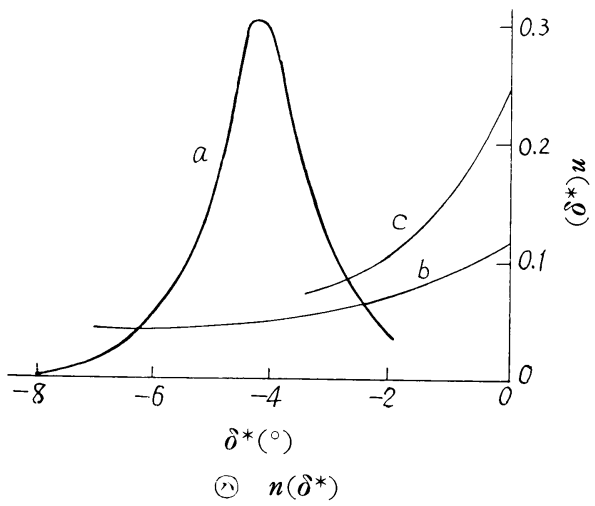

a : 下限制限の場合

b : 上限制限の場合 (下限は自然状態)

c：上限制限の場合（下限を一 $-3.5^{\circ}$ に制限）

b, c については $\delta_{\text {max }}{ }^{*}=0^{\circ}$ を仮定

(第13図) $n\left(\delta^{*}\right)$ の検討
れらの原因は図回から説明できる， $K_{V}$ の増加で， $P$ の 值が非常に小さくなったとき，ローラーBへの繊維付着 はまだらであり，しかも繊維の付着位置はローラーBの 特定の位置に限られる。つまり，この部分の針状態が異 常なために繊維はローラーBに移動するが，針状態を修 正するならば繊維の移動は完全になくなるはずである. 図回において・印については $K_{V}=0.4 ， 0.45$ のの測 定値, ○印については $K_{V}=0.35$ 付近の $P$ の測定值が, このような理由で大きな値となったのである。

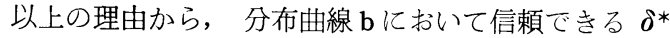

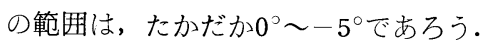

以上, 曲線aならびに曲線 bについて，信頼できる区 間を考え合わせると, $n\left(\delta^{*}\right)$ は $\delta^{*}$ が $0^{\circ}$ 付近にピークを あち-8 付近まで指数関数的に減少する分布形を示す確 率密度関数であると結論できる.

\section{4. 結 語}

カージング ローラー間の繊維移動率 $P$ は種々の要因 に影響される值であるが，1本の繊維に注目した繊維移 動モデルを用いることによって，乙れを統一的に説明す

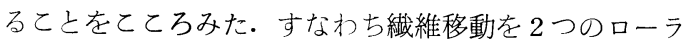
一による繊維の把持現象上，その把持繊維がいずれかの ローラーに移動する分離現象之に分け， $n(\grave{\delta}) 之[\Delta \phi]$ を定義し，多くの実験結果を整理した。

本報で得ら机た $\Delta \Delta \phi], n(\overbrace{}^{*})$ に関する知見は力ージ ングローラーの工業的利用において, 有効な設計資料之 なることを付言する。な拧，カージングローラーの設 計についての検討は次報で報告する予定である。

本研究に対し乍益な則論をいただいた東京工業大学・ 石川章一, 清水二郎, 酒井啠也諸先生に深く感謝の意を 表する。

なお，本報文の一部は日本繊維機械学会第23回年次大 会, および東海地方大会（1970.11.27）で発表した.

\section{参落文献}

1) $\lceil$ Wool Research $\rfloor:$ p.62 Wool Industries Research Association, Leeds (1948)

2) D. Kaufmann : Textil-Praxis, $984(1962-10)$

3) Yu.A. Baturin : Textile Ind. USSR, 37, No.4 (1964)

4) 原川・田中：瀻機誌，22， T 126 (1969） 